\title{
The Publication of "Mrs. Dalgairns' Cookery": A Fortuitous Nineteenth-Century Success Story ${ }^{I}$
}

\author{
Mary F. Williamson ${ }^{2}$
}

In March 1829, I500 copies of Mrs. Dalgairns's The Practice of Cookery were released to the public by an impatient author and her obliging publisher Robert Cadell of Edinburgh, along with his London agents Simpkin \& Marshall ${ }^{3}$ (fig.I). Its publication was preceded by notices in the leading newspapers of Edinburgh, London, and Dublin, including a half-inch advertisement in The Times. The cookbook, priced at $7 \mathrm{~s}$ $6 \mathrm{~d}$, was an immediate commercial and critical success, and Cadell and his successors were to benefit from 30 years of steady sales of I6 editions from I829 until I86r. In that year Mrs. Beeton's sumptuous Book of Household Management was first published, crushing the competition. While the celebrated Mrs. Beeton compensated for her ignorance of cookery by cutting and pasting from the work of her predecessors, Mrs. Dalgairns was an original.

The name "Mrs. Dalgairns" is known today only to culinary history cognoscenti, cookbook collectors, and writers on Scottish cookery. In I829 one might have predicted otherwise. The sheer size

I Earlier versions of this article were presented in 2006 at the conference of the British Association for Canadian Studies and the Fall Colloquium of the Scottish Studies Foundation at the University of Guelph.

2 Retired as Fine Arts Bibliographer in the York University Libraries, Mary F. Williamson continues as an Adjunct Faculty member in the Graduate Program in Art History. She is a collector of early cookbooks, and writes and lectures on 19th and early 2oth century culinary history.

3 The story surrounding the publication of this book can be traced in the Cadell Papers, MS 744-745, 793-803, 2100I-69, National Library of Scotland (hereinafter, NLS). The collection has been microfilmed by Adam Matthew Publications in a series entitled "Nineteenth Century Literary Manuscripts." Part 7 contains "Correspondence and Papers of Robert Cadell," reels I-22. A finding aid linking reel numbers to MS numbers is found on the microfilm publisher's website <http://www.adam-matthew-publications.co.uk/collections_ az/ninethclm-7cad/contents-of-reels.aspx?h=cadell $>$. The relevant folders in the collection relate to letters to and from Mrs. Dalgairns ("E.C. Dalgairns") I829 to I830; letters to and from Captain Basil Hall; Cadell's diaries up to his death in I849; correspondence with his London agents; accounts; scrapbooks and records of advertisements placed, etc. 


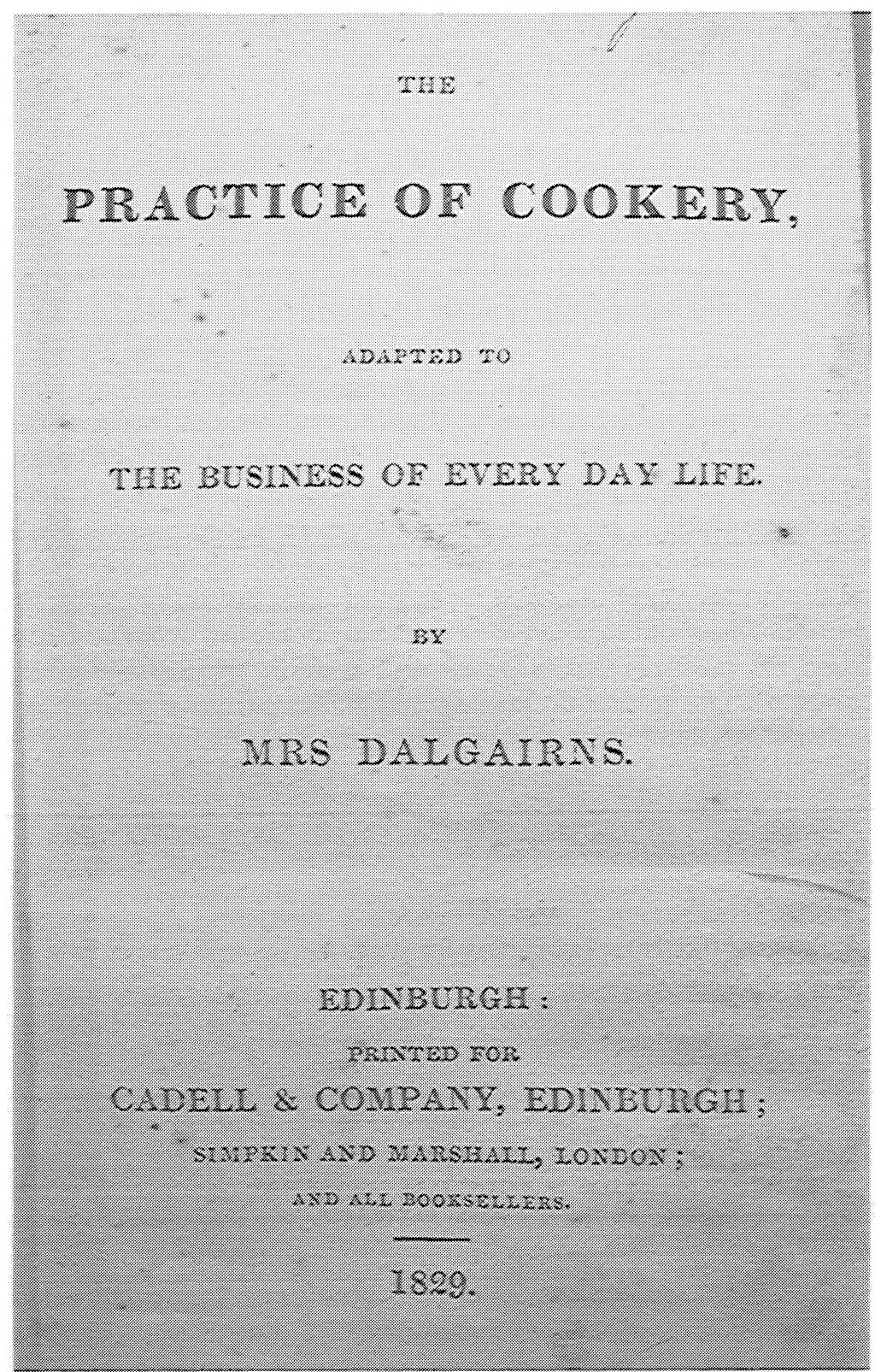

Figure I. Title page of the Ist edition of The Practice of Cookery (I829).

Reproduction courtesy M. Williamson's private collection. 
and eclectic range of The Practice of Cookery is impressive. The author had absorbed the tastes of her friends and family in Prince Edward Island, and of the Scottish gentry into which she had married, and in doing so embraces the cuisines of Europe, Asia, and North America. Rather than simply copy from earlier cookbooks like many of her predecessors, Mrs. Dalgairns took pains to carry out comparative research in her kitchen. The result was a work that today might be termed multicultural, but this should not seem surprising after one has followed the trail from Charlottetown to Dundee, Scotland.

At least a dozen reviews - all favourable - appeared between March and June 1829 in Scottish and English newspapers, literary magazines, and the 'ladies' press. $^{4}$ The Spectator compared Mrs. Dalgairns with Mrs. Rundell and Dr. Kitchiner, two names that resonated in the kitchens of the English-speaking world, declaring Mrs. Dalgairns to be "far more copious than they are, far more various, and to us more novel." By its third edition in 1830, Mrs. Dalgairns had achieved enviable recognition for her name: the advertisements for the cookbook and the stamped binding simply bore the title "Mrs. Dalgairns' Cookery." One reviewer did raise a quibble that the author exhibited "too palpable an addiction to Scotch dishes." Ironically the reviewer could not have known that Catherine Emily Dalgairns was not a Scot, but a British North American, born, bred and married in Prince Edward Island. Her origins may explain her natural interest in drawing together foods from cultures on several continents. Far from emphasizing Scottish foods, the I434 recipes in the first edition of The Practice of Cookery underline the existence of a world of international foods that for generations had been consumed by Scots of the middle and upper classes. At the same time their variety betrays the author's own diverse roots.

4 Reviews of The Practice of Cookery so far uncovered: The Edinburgh Literary Journal, or, Weekly Register of Criticism \& Belles Lettres i8 April 1829: 314; Caledonian Mercury 25 April 1829: 3; The Scots Times 25 April 1829:170; The Mirror of Literature, Amusement, and Instruction 25 April 1829: 28I-82; Edinburgh Weekly Journal I3 May I829:I46; The Spectator I3 June I829: 380; La Belle Assemblée 5 (June 1829): 277-78; The Lady's Magazine ns Io (June 1829): 322; The Ladies' Museum, 4th ser., 2 (Sept. 1829): 174; Edinburgh Observer (? I829) - an extract from a review was used in an advertisement, but the newspaper itself has not survived; Gentleman's Magazine Ioo (July I830): 59; and Foreign Quarterly Review 33 (April 1844): 109.

5 The Spectator I3 June 1829: 380.

6 Foreign Quarterly Review 33 (Apr. 1844): I09. 
As the daughter of Phillips Callbeck, Attorney-General of St. John's Island (later named Prince Edward Island), who during the American Revolution had been deputized as Governor, Catherine Emily was a member of a leading PEI family. Her father is thought by the Callbecks to have been of Irish origin, while his wife, Ann Coffin, was born into a prominent Massachusetts family that had emigrated from southern England in 1642. Two of her uncles joined the Loyalist cause, with Sir Isaac Coffin assigned ownership of the Magdalen Islands as a reward for his services. Phillips Callbeck owned the only store in the colonial island outpost, and of necessity the family made frequent expeditions to Halifax on business and to mingle with their social equals. After her husband's death in I790, Ann Callbeck lived for a time in Halifax with her children, and it is from Halifax that she wrote to Mrs. MacDonald of a prominent family in West River, PEI, to express her satisfaction with the goods that were available in Halifax, including rye flour "which makes excellent brown bread."7

In the early I80os Catherine Emily made the acquaintance of a man who was to play a crucial role in her becoming a published author. Midshipman Basil Hall - son of Sir James Hall of Dunglass, a Baronet of Nova Scotia - had on two occasions in the early I8oos been posted to Halifax for several months. In a letter to Mrs. Martin Hunter, the wife of a colonial administrator in the New Brunswick Council living at the time in Fredericton, Basil's mother was clearly troubled by reports of her son. "I wish I heard of Basil's return from that Island he is gone to," she moaned, as she had heard that Basil was "blabbing his intentions all over Halifax." "Was Basil in pursuit of the future Mrs. Dalgairns? We shall never be sure, but we do know that he was already her good friend, champion, and mentor when in 1828 he introduced her to his publisher, Robert Cadell. Just a few months after Basil had visited the Island, Peter Dalgairns, of a landed Scottish family, married Catherine Emily Callbeck in Charlottetown in a double wedding ceremony with her sister. Like many Scotsmen before him, Peter intended to settle on the Island and had purchased a house in Charlottetown, then a town of fewer

7 Ann Callbeck to Mrs. Macdonald, 29 Sept. 1808. This and other letters written by Ann Callbeck were brought to my attention by e-mail on I9 July 2004 by Charlotte Stewart, Public Services Archivist, Public Archives and Records Office of Prince Edward Island.

8 Helen Hall to (General) Mrs. Hunter, 3 Jan. I808, MS I4I96, p. 75, Hunter Letters, NLS. 
than 500 colonists. But he was soon embroiled in bankruptcy actions - the first of a series - and owed his new brother-in-law substantial sums. With debts to be settled by sales of the timber rights on lands he had purchased, Peter and his bride departed for England, eventually settling near the docks in London. For Catherine Emily, a new life in the cosmopolitan heart of the empire may have compensated for the distress of the bankruptcy. ${ }^{9}$

By I822, Peter and Catherine Emily had left London and were residents in Dundee on the east coast of Scotland, just a short carriage ride from the parish of Eassie \& Nevay, home to the Dalgairns family estate of "Ingliston." The house still stands, and the nearby parish cemetery that was attached to a ruined church shelters large gravestones inscribed with the names of Peter's parents and siblings. In London, Peter had become a wine merchant, a trade which he followed in Dundee where on Shore Terrace, facing the busy harbour, the childless couple and their servants - including her cook Anna Prophet - lived in apartments above the wine business. Peter was listed in city directories with the "Nobility, Gentry and Clergy," and his name was mentioned from time to time as a company director. He was also regularly listed as a bankrupt whose assets were to be sold off, but Peter still managed to maintain a respectable position in the community.

Captain Basil Hall's sister-in-law, Jane Hunter Guthrie, also lived in Dundee at the Guthrie family seat "Craigie," a substantial property at the north end of town. In his correspondence the Captain is found making regular family visits to Dundee, and surely occasional detours to spend some time near the harbour with his old friend. Mrs. Dalgairns had named Jane's husband, who was a banker, together with Peter's brother, Andrew Dalgairns, as trustees for her royalties.

Mrs. Dalgairns would have been in the advanced stages of collecting and testing recipes when in April 1827, Captain Basil Hall and his wife Margaret and their daughter began a year-long tour of North America. The trip included several days in Upper Canada and the Peterborough area where Basil was bent on finding out all he could about Peter Robinson's immigration scheme, and Margaret made observations on the living conditions of settlers such as Thomas and

9 Peter Dalgairns's bankruptcies can be followed in The Times for 3 June I8II, 29 March I8I9, 27 August I833, and 26 August 1848, and for I833-36 and I848-52 in the Sequestration records, CS 46/7I and CS 280/38/35/1, National Archives of Scotland. 
Frances Stewart. ${ }^{\mathrm{IO}}$ The Captain had hoped to make a nostalgic trip to Halifax during the journey, looking "forward to visiting Halifax with greater pleasure than to any part of our projected tour," ${ }^{\text {"I }}$ but lack of time prevented the visit, and the family sailed home from New York. Shortly after their return to Scotland letters from the Captain to Robert Cadell are full of talk about the cookbook by his friend Mrs. Dalgairns, and its future publication by the firm. From that moment he proceeded to oversee the cookbook through every step of production, publication, and publicity, reminding Cadell from time to time of his great interest in it. While writing his own book of North American travels, and propelling it through to publication as a handsome two-decker, he managed to act as advisor, agent, and vital contributor to Mrs. Dalgairns's cookbook. The Captain hated to be idle; his behaviour was consistently frenetic, until in his final days before his death in 1844 he had to be confined in a mental institution.

Hall's first communication with Cadell on the subject of the cookbook must have occurred on a visit to Edinburgh immediately after his return from North America. On 7 August 1828, Cadell wrote to Hall enclosing the publication agreement to be passed on to Mrs. Dalgairns (fig. 2):

We most cheerfully agree to take all the risks of One Thousand copies of Mrs. Dalgearns [sic] Cookery Book and pay one half of the gain of said Iooo books 12 mos from publication or when we have only 100 or 50 unsold as you may decide - we also agree to make Mrs. Dalgearns a distinct offer for all future editions prior to going to proofs; you deciding on the number to the printerEso to $\mathrm{a} / \mathrm{c}$ an[d] at Mrs. Dalgearns service whenever she likes. \&c \&c \&c. The Book to go to press immediately and to be published as soon as ready. $\mathrm{RC}^{\mathrm{I} 2}$

Io Basil Hall kept detailed journals of his travels, editing them into a series of travel books, all published by Robert Cadell. His Travels in North America in the Years 1827 and 1828 was published in 1829 , closely followed by a collection of 40 etchings based on the tour. His wife wrote regularly to her sister Jane, and in I93I a collection of the letters, edited by Una Pope-Hennessy and omitting the travels in the Canadas, was published by Putnam in New York as The Aristocratic Journey: Being The Outspoken Letters of Mrs. Basil Hall written during a fourteen months' sojourn in America, I827-1828. The original manuscript that includes the Canadian section of the tour is in the Library of Congress ( $\mathrm{mm}$ 8IO2452I) with a photocopy in Library and Archives Canada.

II Margaret Hall to Mrs. Hunter, 7 Nov. I827, p. 35, MS I4196, Hunter Letters.

I2 Robert Cadell to Basil Hall, 7 Aug. I828, p. I8, Accounts 21056, Cadell Papers. The initial contract stipulated tooo copies, but this figure was quickly raised 


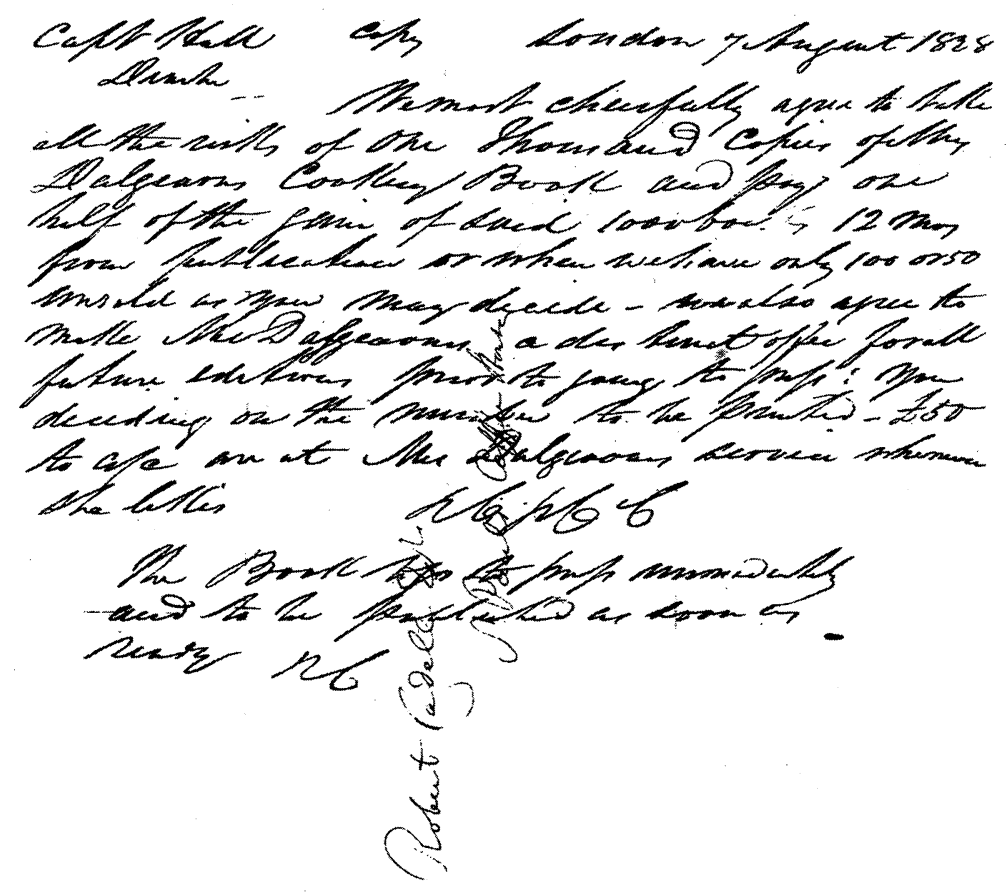

Figure 2. Robert Cadell's agreement with Mrs. Dalgairns. Cadell to Hall, 7 Aug 1828, Cadell Papers, MS 21007.

Hall responded immediately:

Your offer about Mrs. D. is very kind and I shall take care to mention it - but in the meantime take no steps - of any kind, till I communicate with the Lady. I shall recommend her to see you in Edinburgh or at all events to write to you there. Should she go to you, I need not ask you to be kind to her. In the mean

to 1500 copies. Subsequent editions were printed in I500 copies. Booksellers paid $4 \mathrm{~s}$ IId for each copy which sold for $7 \mathrm{~s} 6 \mathrm{~d}$. In his letter to Basil Hall of $\mathrm{I}_{4}$ September 1829, Cadell agreed to pay I shilling per copy to Mrs. Dalgairns; in his letter to her of I May 1830 he wrote that he owed her $\mathfrak{E}_{75}$ for the second edition; and on 16 August 1833 , she acknowledged receipt of $\mathfrak{E} 75$ which would have represented the royalties on the 4 th edition. 
time will you oblige me by writing a few lines in addition to the enclosed estimate on the $3^{\text {rd }}$ page - stating your wishes as to the work in question $-\&$ then I shall send the whole to her for her affectation. ${ }^{13}$

The project, it seems, was well underway, even though the publisher had not yet seen the author's name in writing and misspelled it. From then on, Hall corresponded with Cadell weekly and sometimes daily on some aspect of the work. The Captain had some familiarity with cookbooks, and at one time he had hoped that Cadell would improve on the usual format of the genre: "At first sight, I should have thought a new form preferable to an old one - but upon consideration I am of opinion that you will do well to keep to that size, \& general appearance which the public are familiar with." Like the publisher, the Captain was always conscious of costs, and with a new author there would be risks. Cadell's main business - and a highly lucrative one - was as publisher of Sir Walter Scott. He was in the process of planning for both cheap and illustrated editions of the novels that would continue to maintain his family in grand style. That Cadell spent so much time dealing in a generous manner with the Captain's constant burbling - even the Captain admitted to meddling - indicates his respect for the prolific travel writer who in his own way continued to generate profits for the business. Between them the two discussed every aspect of the cookbook, starting with the index. To his credit, Cadell had strong views on indexes. As the long time co-publisher of Dr. William Kitchiner's The Cook's Oracle, he knew his audience: ${ }^{\mathrm{I}}$ "Few read cookery books end on. It is all a reference, more especially when the Book acquires an established reputation.... I am rather inclined at present to recommend leaving out all the Contents of the Chapters. I hear many ladies say that they never look at them. They invariably refer to the Index. For there is a copious Index which is always consulted, the Contents never. In place therefore of Contents to each chapter, I would reverse the matter as to the Index and place it immediately after the Preface and before the body of the Book, not after."

I3 Hall to Cadell, 7 Aug. 1828, p. 5, MS 21007, Cadell Papers.

I4 Cadell published The Cook's Oracle during the 1820 s and 1830 , and in 1833 he purchased the copyright for $£ 500$ from Whittaker in London.

I5 Cadell to Hall, 23 Aug. 1828, p. 306, MS 793, Cadell Papers. As Cadell intended, in the first edition the Index occupied 26 pages immediately following the Preface. In her biography of Mrs. Beeton, Kathryn Hughes writes that while 
unwilling to drop the list of chapters: "I am quite of your mind about the Index - a copious Index, however, - with the same article inserted under half a dozen different heads, if possible, in order to prevent the possibility of disappointment in the search. Nevertheless a brief, clear Table of contents - not extending beyond one page, would, I think, be a good thing - running thus ..." and he drew a design for a list of chapters and their contents. Thus the list of chapters was maintained in the Preface through to the I6th edition, and as recipes were added with each new edition, the number of recipes found in each chapter was updated. The topics in the 25 chapters covered in The Practice of Cookery range beyond the usual expectations of a cookbook; the final chapters deal with the kitchen garden, the dairy, beekeeping, and animal husbandry. ${ }^{16}$

Two pages of proofs were ready to be checked by the author, and Mrs. Dalgairns visited Edinburgh for a week in August I828, staying with friends. Basil Hall was insistent that while she was in the city she should learn a little about the printer's trade, in particular to acquaint herself with printers' marks which were "not easily explained ... at a distance." The lady was eager and impatient, and Cadell anticipated a November publication date. "Rely on it," he wrote to the Captain, "no whim wham shall now lose it. I have no doubt of the book being a good one.... I think it will keep its ground." ${ }^{17}$ They discussed a title, with various suggestions bandied about. There was agreement that there should be a suggestion of "practicality." In the end, the Captain decided on "The Practice of Cookery by Mrs. Dalgairns," and in a coach on his way to Edinburgh scribbled a note to say "You know there is the Practice of Medicine, The Practice of Seamanship $\&$ other things $\&$ 'what for no' - The Practice of Cookery?” Two

Mrs. Beeton was thought to be the first cookbook compiler to include a comprehensive index, it had been noticed that The Practical Housewife of 1855 had "led the way" (Kathryn Hughes, The Short Life \& Long Times of Mrs. Beeton [London: Fourth Estate, 2005], 24I-42). However, The Practice of Cookery, first published 26 years earlier, had just such a comprehensive index at the front.

I6 Hall to Cadell, 25 Aug. I828, p. IO, MS 21007, Cadell Papers. List of the Chapters: Soups; Fish; Mutton; Lamb; Veal; Pork; Poultry; Curries; Game; Gravies, Sauces, \&c.; Vegetables; Puddings, Pies, and Tarts; Creams, Custards, \&c. \&c.; Cakes, \&c. \&c.; Preserves; Vinegar and Pickles; Domestic Wines; Miscellany; Poultry Yard; Dairy; Brewing; Kitchen Garden; Bees; Pigs; Appendix. After 1834, an Appendix II was created for additional recipes, and in posthumous editions published in the 1850 s and I86os an Appendix III brought in 22 more new recipes.

I7 Cadell to Hall, 23 Aug. I828, p. 306, MS 793, Cadell Papers. 
days later he was worried that Cadell had not received his note: "the more I think of it the more I like it - 'The Practice of Cookery' - it is simple, \& expressive $\&$ is true to the circumstances in hand, nor does it interfere, as far as I know, with anyone - and it has just enough of quaintness to lift it above common place language, without carrying it into mystery, or foffery of style." " 8 The title did, in fact, "interfere" with someone. A cookbook by Mrs. Frazer, who conducted a cookery school in Edinburgh, bore the same title, and had been published in at least eight editions from I79I to I827, but it is not surprising that the two gentlemen were unaware of a cookery textbook.

At the end of 1828 the Captain asked Cadell for a date when he would require the Preface. He then suggested the wording for an "N.B." as he called it: "This Volume contains a Complete System of Practical Cookery - expressly adapted to the business of every day life," out of which "adapted to the business of every day life" became the cookbook's subtitle. Hall endlessly deliberated on the "puff," writing that "well known established works are improved by puffs - those which are well known are helped thereby.... Both Kitchener $[s i c]$ \& Mrs. Dalgairns, however, will be the better of such lifts - done with great care \& discretion.... Tell me, if you please, exactly how many lines you can afford for Mrs. Dalgairns \& I will turn the puff over $\&$ over in my mind."' The puff was needed for the initial advertisements until favourable reviews could be extracted, and subsequently Margaret Hall was to deny to Mrs. Hunter that Basil had written it. ${ }^{20}$ Captain Hall busied himself during the winter reading proofs of the I2-page Preface, returning them "doctored" and cut down. He demanded and read further revises or proofs and criticized the choice of paper for the book.

At the last minute the Captain urged Cadell to slip in an insertion: "I send ... an additional receipt for which there is room at page 444. Pray take great care to see it correctly printed. Don't tell Mrs. Dalgairns any thing about it - till she sees it." It was his own invention: "Captain Hall's Sandwiches for Travellers" (fig. 3). Cadell questioned the recipe, whereupon Hall advised that the loaf had to be circular for the sides of the sandwich to fit properly. ${ }^{2 \mathrm{I}}$

I8 Hall to Cadell, 3I Aug. I828, p. 16, MS 21007, Cadell Papers.

I9 Hall to Cadell, 6 Jan. 1829, p. 86, MS 21007, Cadell Papers.

20 Margaret Hunter Hall to (General) Mrs. Martin Hunter, I4 May 1829, p. 5I, MS I4196, Hunter Letters.

2I Hall to Cadell, I8 Jan. I829, p. 94, and 23 Jan. I829, p. 96, MS 21007, Cadell Papers. 


\title{
Captain Hall's Sandwiches for Travellers.
}

\begin{abstract}
Spread butter, very thinly, upon the upper part of a stale loaf of bread cut very smooth, and then cut off the slice; now cut off another thin slice, but spread it with butter on the under side, without which precaution the two slices of bread will not fit one another. Next take some cold beef, or ham, and cut it into very minute particles. Sprinkle these thickly over the butter, and, having added a little mustard, put the slices face to face, and press them together. Lastly, cut the whole into four equal portions, each of which is to be wrapped in a separate piece of paper.
\end{abstract}

Figure 3. "Captain Hall's Sandwiches for Travellers," from the first edition (I829), p. 444.

Unexplained delays held back the cookbook until March I829. By that time Captain Hall had made sure that the chapter on Medicine was excised. He recognized that cookery books often ended with such a chapter, but he was convinced it was out of place, even though he suspected the author had a "hankering" after it. "Some other cookery books have it," he wrote to Cadell, "but really I don't think that a sufficient reason for keeping it in - however well done. Surely nothing can be worse than encouraging people to do without medical advice in such a country as this." 22 This was most definitely not the kind of cookbook that was directed at lower middle class housewives who, lacking access to professional advice, routinely stepped in as nurse and doctor to their households.

Through the autumn of 1828 the Captain had been reading proofs and suggesting typographic corrections. It was about this time that he began to lecture Cadell on the usefulness of stereotyping which for this book did not appeal to the publisher. The Captain believed stereotyping worth the extra expense, even if the success of the book were not assured, but in December of 1829 he was promoting it for another very practical reason: "I hope you begin to feel the comfort of the stereotype plates, which enable you to work in daylight instead of

22 Hall to Cadell, 3r Aug. 1828, p. 16, MS 21007, Cadell Papers. 
groping \& guessing in the dark." ${ }^{23}$ By March I830, however, he had changed his tune with respect to Mrs. Dalgairns who was pressuring Cadell to issue new enlarged editions: "The more I reflect upon the subject, the more I am satisfied that except in those particular works, such as that of Mrs. Dalgairns, when changes must constantly occur, stereotyping will be found a great saving both of money $\&$ of anxiety to the Publisher $\&$ author. ${ }^{24} \mathrm{New}$ editions of The Practice of Cookery continued to be typeset until the sth edition in 1834 when stereotyping put an end to expanded chapters. Additional recipes were listed unindexed in Appendix II.

Basil Hall's recent travel book had been savaged by The Scotsman and criticized elsewhere, and the Captain indicated that he doubted reviews influenced sales of a book. But positive reviews which could be read in British journals commonly reprinted in America and in the colonies, surely boosted sales of The Practice of Cookery. Readers of the Edinburgh Weekly Journal may have hurried to the local bookseller on being told by the reviewer that he was "almost tired of Cookery Books," but "it having leaked out that Captain Basil Hall has good-naturedly provided the preface of the work," his interest was piqued. He remarked on the "diligence used to collect and collate the materials," and concluded that the cookbook would "take the lead of all its companions, and maintain its ascendance afterwards. ${ }^{25}$ The first run of 1500 copies quickly sold out. An abbreviated American edition was published in New York and Boston, omitting the final chapters that were not about cookery.

At first Cadell was wary of the risk to his firm in publishing an unknown author and put more than the usual funds into publicity. But his attitude was to change. He had sent 25 copies to his London co-publishers Simpkin and Marshall, plus "sundry copies for reviews, etc., and I2 extra for you to give to such others as you think will do the book good." ${ }^{26}$ He reminded the London publisher that their friend Captain Hall had a great interest in it. In spite of the positive reviews and plans for an immediate second edition, Cadell wrote in August to Captain Hall that he couldn't look beyond the 2nd, and if "I decline to risk any more she is to have a right to carry the book to

23 Hall to Cadell, 6 Dec. I829, p. I42, MS 21007, Cadell Papers.

24 Hall to Cadell, 30 Mar. 1830, p. 185, MS 21007, Cadell Papers.

25 Edinburgh Weekly Journal I3 May I829: 146.

26 Robert Cadell to Messrs. Simpkin \& Marshall, Io Apr. I829, p. 47, MS 797 , Cadell Papers. 
a more liberal Bookseller. ${ }^{27}$ Robert Cadell was accustomed to backing sure bestsellers such as Sir Walter Scott's novels and Kitchiner's The Cook's Oracle.

The first letters between Mrs. ("E.C.") Dalgairns and Robert Cadell appear in the Cadell Papers in May I830 when a new edition was being planned. In the meantime the cookbook had achieved critical and financial success. Robert Cadell kept the Captain informed about sales, and Hall in turn expressed his appreciation for the regular reports. But sales of the cookbook were beginning to rival those of Captain Hall's travel book. "I need not say to you that I rejoice exceedingly at the continued success of Mrs. Dalgairns," he wrote on 2 February I830 from Paris; "We are neck \& neck just now - but I dare swear the belly will beat the head in time - we shall see." ${ }^{28}$ The second edition with added recipes was published in November I829, and a third edition in the Spring of 1830 . Subsequent "editions" were simply added impressions of 1500 copies each. The Preface to the fourth edition (I83I) acknowledges that "every receipt in this Work has been carefully revised for this Edition, in order that advantage might be taken of the numerous valuable criticisms by which it has been honoured in all parts of the Empire." In 1833, believing that the time had come for an expanded edition, the author wrote Cadell: "I have had some contributions towards [a new edition]." She thanked Cadell for expressing sympathy for "our distressing situation," referring to Peter's latest bankruptcy. But she was unhappy about the current state of the cookbook. "I wish that our Book would circulate more readily than it seems to do," she continued on this theme in her next letter, for "upon comparison with others of the same description it ought to be more valued." She hoped that another edition was required. ${ }^{29}$ Two weeks later a bank order for $\mathfrak{E}_{75}$ representing the royalties from the 4th edition was mailed to her trust fund, but Cadell demurred on a sth edition. He also advised her that the price of the cookbook would be dropped to 5 shillings "in the present taste for cheap books," although he was certain the result would be increased sales and higher income. ${ }^{30}$ By November she had reluctantly acquiesced in the reduced price of her cookbook, but Cadell compromised and the new price was set at 6 shillings. In this letter she confessed to suffering from

27 Cadell to Hall, I4 Sept. I829, p. 331, MS 793, Cadell Papers.

28 Hall to Cadell, 2 Feb. I830, p. 167, MS 21007, Cadell Papers.

29 Dalgairns to Cadell, I6 Aug. I833, p. 233, MS 21003, Cadell Papers.

30 Cadell to Mrs. Dalgairns, 30 Aug. 1833, p. 234, MS 21003, Cadell Papers. 
"a long illness ... which has debilitated me so much that it will be some time before I am able to study even a Cookery Book." ${ }^{\mathrm{I}}$ Six years later, she was "too much of an invalid to make any exertion," but was well enough to forward 60 more receipts to be added to the end of the book. Well aware that additions to a stereotyped text involved unwelcome expense, she suggested that "They go into so small a compass when in Print that the difference in the size of the Book should be trifling to a degree." ${ }^{2}$ Five years later, on I March I844, Mrs. Dalgairns died, a fact recorded by Cadell in his diary the next day.

By this time, Robert Cadell was a player in the general debate on copyright reform that led to the new Copyright Act of 1842. His main concern was with the Sir Walter Scott copyrights that were due to expire that year, but fortunately were extended by the Act for I4 more years. But also he was worried about his own failing health and the state of his personal finances. "I am purchaseable! I wish to retire," he wrote to his friend A. Cowan. ${ }^{33}$ Plans for four London sales of his entire stock and copyrights in I848 and I849 were cut in half by his death in January I849, but The Practice of Cookery was one property that had not been sold, and a further IIth and I2th editions were issued in 1849 and 1850. By 1854 Richard Griffin, a Glasgow publisher who had moved his firm to London, had assumed the rights to the cookbook, issuing several often undated editions up to I86I (fig. 4), all of them with an Appendix III that was not the work of Mrs. Dalgairns.

During the ten years she spent revising her cookbook, there were criticisms, and suggestions, and opportunities to plagiarize, but Mrs. Dalgairns took little notice of them. Early in I830 Cadell forwarded a copy of Eustache Ude's popular The French Cook, thinking it would be of interest. ${ }^{34}$ On 16 August I833, she sought from Cadell two cookbooks - preferably second hand - "which I am told may be of service to me": The Lady's Own Cookery Book by Lady Catherine Bury, a title that is rarely seen today, and another uncommon title - John Conrade Cooke's Cookery and Confectionary. Neither cookbook

3I Dalgairns to Cadell, II Nov. 1833, p. 259, MS 21003, Cadell Papers.

32 Dalgairns to Cadell, 8 Nov. 1839, p. 278, MS 21004, Cadell Papers.

33 Cadell to Cowan, 23 Mar. 1848, p. 264, MS 21006, General Correspondence, Cadell Papers.

34 In his diary entry for 20 Jan 1830 , Cadell wrote that he had sent her a "French Cookery Book" which must have been Ude, first published in 1815 (Diaries, MS 21020, Cadell Papers). 


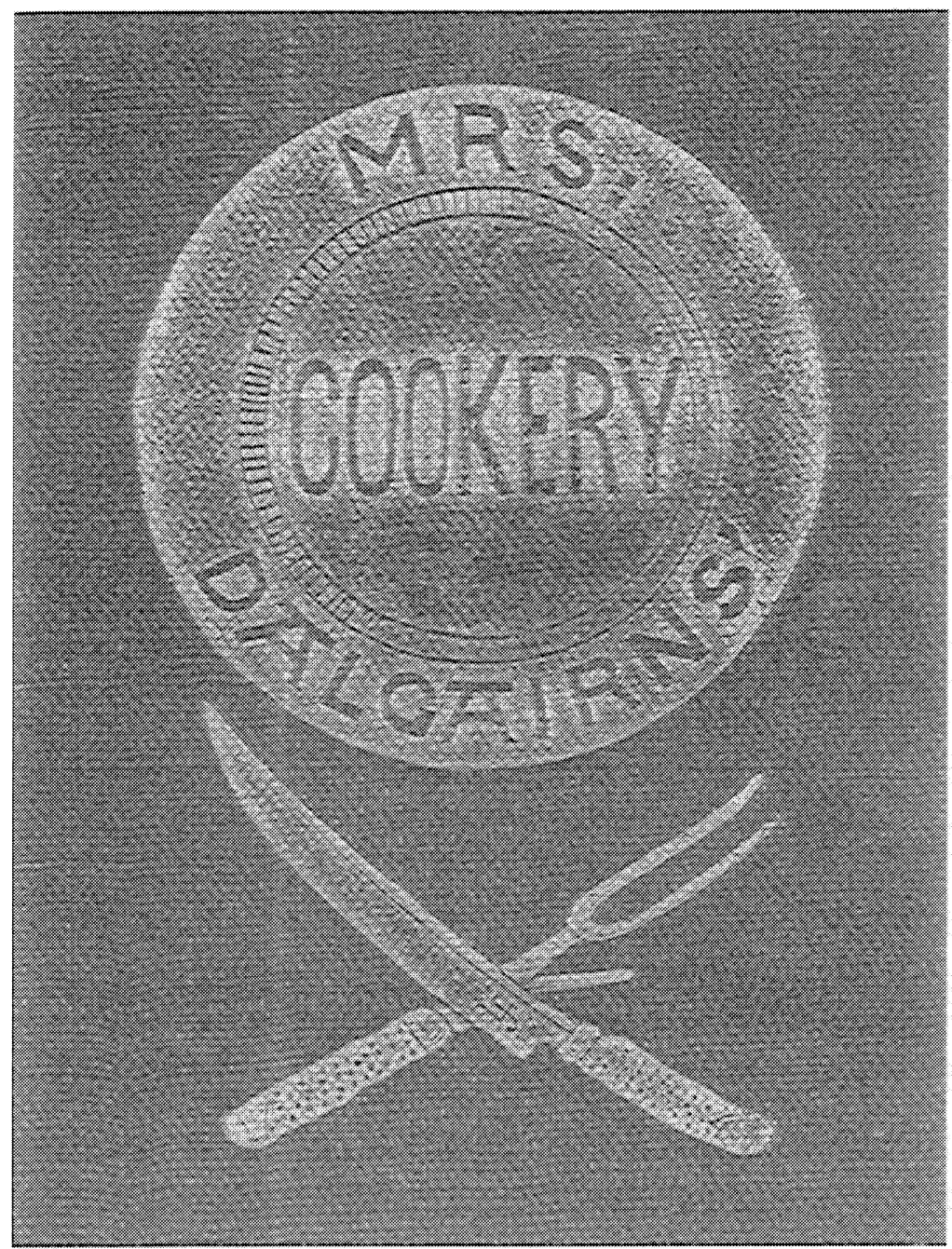

Figure 4. Detail of stamped-cover design of the I6th edition (I86I). Reproduced from a copy held in the collection of the National Library of Scotland. 
appears to have been used as a source for a new edition. Nor was La Cuisinière Bourgeoise, a copy of which was sent by Captain Hall from Paris in the belief that as a "citizens" book of cookery, and very popular in that city, "it cannot fail to furnish some useful hints for the next Edition." 35

Alas, little is known today about the reactions of individual cooks at that time to new cookbooks as they tried to follow the recipes in the kitchen. In the case of Mrs. Dalgairns a few contemporary criticisms survive and shed some light, focussing on individual recipes. For example, Captain Hall's household was in possession of the cookbook as soon as it was published. That his wife was using it we know from a letter she wrote to Mrs. Hunter who had been acquainted with the Callbeck family in Halifax. Margaret Hall began by telling her correspondent that "you will be glad to hear that her book is selling remarkably well. I recommend 'Lemon Pudding' \& 'Rich Pudding' to your notice, with half the quantity of butter mentioned in the receipt, and 'Apple Pudding' without any butter at all. We have tried those three in this way and found them excellent" ${ }^{36}$ A reduction in the butter content was as welcome then as now!

On 30 August I833, when Cadell consulted Mrs. Dalgairns about a possible new edition, he referred to his wife and other female members of his household, complaining that "My Ladies doubt your preserving recipes, they do not find them to answer, how would it do to give a few nice ones in their way." Mrs. Dalgairns replied at once: "I regret to hear that your Lady friends find any inaccuracies in my Preserving receipts as I have thought a great deal of them particularly, and have always found them answer as have many others who highly approve of them." Brushing off the implied criticism, she thanked Cadell effusively, taking this as an opportunity to press for the new edition when any necessary improvements and additions could be made. ${ }^{37}$ No changes were made, but the new Appendix II added recipes for "Preserved Tomatas" and "Tomata Catsup."

The editor of the ladies' magazine La Belle Assemblée himself reviewed The Practice of Cookery, declaring it to be "the very best compilation that he has ever had the pleasure of meeting with,"

35 Hall to Cadell, 6 Dec. 1829, p.I42-43, MS 21007, Cadell Papers.

36 Margaret Hunter Hall to (General) Mrs. Hunter (later Lady Jean Hunter), I4 May I829, p.5I, MS I4196, Hunter Letters, NLS.

37 Cadell to Mrs. Dalgairns, 30 Aug. 1833, p.234, and Mrs. Dalgairns to Cadell, II Nov.I833, p.259, MS 21003, Cadell Papers. 
but that he "takes leave to say, from his own knowledge, that the soda-water, prescribed by Mrs. Dalgairns, has vastly too much acid in it, and, consequently, is by no means congenial to the human stomach." He continued: "If Mrs. Dalgairns will favour him with a note, previously to the publication of her next edition, the [editor] will be most happy to transmit to her the copy of a much superior recipe for the instantaneous production of soda water, with another for aerated ginger beer, \&c." ${ }^{38}$ An additional unsourced recipe for soda water was introduced after the La Belle Assemblee review.

Unfortunately, the surviving catalogues of nineteenth-century booksellers are scarce, scattered in libraries and private collections. However, there are some indications of how widely "Mrs. Dalgairns' Cookery" circulated. There was the American edition published in I830 by Munroe \& Francis of Boston and Charles S. Francis of New York. Mrs. N.K.M. Lee of Boston evidently owned a copy of the American edition and used it as the source for Burdwan Stew - and other recipes - in her pioneering The Cook's Own Book (Boston: Munroe and Francis, I832.) In Paris, Captain Hall had spoken about the cookbook to the bookseller G.A. Galignani, whose firm specialized in English-language books, and in March I830, 25 copies were shipped by Cadell into the heartland of French cookery. ${ }^{39}$ In Canada, booksellers Samuel Neilson of Quebec City and Armour \& Ramsay of Montreal, who also placed notices in the Kingston papers, advertised The Practice of Cookery to book buyers in the Canadas. ${ }^{40}$ An indication that the name "Mrs. Dalgairns" had by 1836 become recognizable in the colonies is suggested by a reference in the works of Catherine Parr Traill. In an anecdote about a rough carriage ride from the town to her backwoods home near Peterborough, Upper Canada, Mrs. Traill imagined out of the jumble made of her newly purchased groceries "a bush pudding that would cut quite a figure" in Mrs. Dalgairns's The Practice of Cookery. ${ }^{4}$.

A curious notion circulated about the true authorship of the cookbook. In an omnibus survey of culinary literature in the Foreign

38 La Belle Assemblée 5 (June 1829): 277-78.

39 Cadell to Galignagni, 27 March I830, p. 457, MS 793, Cadell Papers.

40 Advertisement for "Books received by the Ottawa and British Sovereign, for sale by Neilson \& Cowan, 3, Mountain Street," Quebec Gazette 31 December 1829; Armour \& Ramsay, Catalogue of Books in the Various Departments of Science and General Literature (Montreal: Montreal Gazette, 1836), 26.

4I Catharine Parr Traill, The Backwoods of Canada (London: C. Knight, I836), I24. 
Quarterly Review for April I844, the reviewer wrote: "We have heard, and believe, that Sir Walter Scott contributed largely to this work"(IO9). The only plausible explanation for this invention is that the reviewer had confused Mrs. Dalgairns with Mistress Margaret Dods whose Cook and Housewife's Manual of 1826 drew its lore from Scott's St. Ronan's Well and the world of the Cleikum Inn. But the story of Sir Walter Scott's involvement persisted; in I860 a Norwich, England, bookseller, E. Jeans, advertised The Practice of Cookery, Adapted to the Business of Every Day Life, 1858, for 4s, listing it under "Dalgairns (Mrs. i.e. Sir Walter Scott)"!

In I829 alone, several thousand words were expended on reviews of The Practice of Cookery. Most male reviewers - and virtually all reviewers were male - admired the author's authority, her practicality, her succinct directions, her avoidance of literary fripperies and puns and jokes, and her lack of extravagance. The Gentleman's Magazine viewed the cookbook as "a truly practical and cheap system of Cookery." ${ }^{42}$ But at the same time she was credited with writing a work of "culinary science" (The Ladies' Museum), ${ }^{43}$ a "treasure ... of gastronomical information" (Edinburgh Literary Journal) ${ }^{44}$ and a work that appealed to "epicurean indulgence" (La Belle Assemblee). ${ }^{45}$ Assumptions by reviewers about readers and their cooks who might benefit from using the cookbook ranged from "tradesmen to the country gentleman" (The Spectator), ${ }^{46}$ "families in the middle class of life" (The Lady's Magazine), ${ }^{47}$ "epicures" (The Ladies' Museum), ${ }^{48}$ "persons in the upper class of life not overburthened with wealth" (Foreign Quarterly Review), ${ }^{49}$ to "persons ... who must support a considerable rank in society upon something less than five hundred a year" (Caledonian Mercury).$^{50}$ In the Edinburgh Weekly Journal, the index was praised as copious and well arranged, ${ }^{5 \mathrm{I}}$ which must have delighted Robert Cadell and Basil Hall. The Scots Times reviewer applauded the useful remarks that were placed at the beginning of

\footnotetext{
42 Gentleman's Magazine Ioo (July I830): 59.

43 The Ladies' Museum, 4th ser., 2 (Sept. I829): 174.

44 Edinburgh Literary Journal I8 Apr. 1829: 314.

45 La Belle Assemblée 5 (June 1829): 277-78.

46 The Spectator I3 June 1829: 380.

47 The Lady's Magazine ns Io (June 1829): 322.

48 The Ladies' Museum, 4th ser., 2 (Sept. I829): 174.

49 Foreign Quarterly Review 33 (April 1844): I09.

so Caledonian Mercury 25 April I829: 3.

5I Edinburgh Weekly Journal I3 May I829: I46.
} 
each chapter rather than thrown together in the general introduction, "a decided improvement over former works." ${ }_{22}$

The writer in the Foreign Quarterly Review, who accused Mrs. Dalgairns of sharing the "heinous fault of all Picts," which was an addiction to Scottish dishes, was perhaps not as astute a gourmand as he thought. The fault may lie in his definition of "Scottish dishes," a concept that is misunderstood today. Among the almost 1500 recipes that appeared in the first edition, and close to 1600 in later editions, English, Indian, French, German, and North American dishes far outnumber those traditionally thought to be Scottish. There is one recipe for Haggis, a food which until the eighteenth century was claimed as much by the English as by the Scots. Oatmeal porridge is never mentioned, and as an ingredient oatmeal is found in only I3 recipes. Significantly, one of these is a "soup for the poor." And there is scarcely an English cookbook of the time that did not include Scotch Collops and Cocky Leeky, both being solid citizens of the British culinary repertoire. The Practice of Cookery illustrates how in the early nineteenth century Scottish food was a great deal more varied than ideas of the obligatory "traditional" foods would suggest. Middle and upper middle-class Scots enjoyed elegant fare that bears no resemblance to the stereotypical, often "peasant" foods that commonly grace Burns supper-tables today. Eminent writers on Scottish cookery have taken pains to explain that the Scots common folk had to survive through periods of near famine, but it was different for the gentry. Scotland's links with France under the Auld Alliance, and its status as a trading partner in the European economy, brought continental foods and wines to the tables of those who could afford them. In the case of Dundee, where the Dalgairns were resident, the prosperous textiles industry encouraged imports from northern and southern Europe and from Asia, leading to dramatic changes in the diet of those who had money. The Scottish food historian Marion McNeill explained it this way: "it is not surprising that in the earliest Scottish cookery-books we learn to dress cod in the Dutch way, lobsters in the Italian way, a nowt's tongue in the Polish way, and so forth, as well as numerous dishes à la française." 33 In gathering recipes from all over the globe, Mrs. Dalgairns was continuing this tradition, and she added at least two more "ways" from her own extended family: North American and Southeast Asian.

52 The Scots Times 25 Apr. 1829: 170.

53 F. Marian McNeill, The Scots Kitchen (Edinburgh: Blackie \& Sons, 1929), 34. 
Among several clearly identified North American recipes in the collection are Potted Lobsters; a moulded Blancmange that is intensely flavoured; Snowballs, which are spicy apples baked in a rice coating; Indian pudding - still a corn-based American favourite; and Gingerbread. The precise directions Mrs. Dalgairns gives in the cookbook for these dishes are untraceable to the usual printed sources. It may be that these, as well as recipes for English dishes, were passed on to her by her mother Ann Callbeck who in the ten years before her death in 1826 lived in southern England.

From the outset, Mrs. Dalgairns included a remarkable number of recipes from the Indian sub-continent. Twenty years before the first Anglo-Indian cookbook was published, ${ }^{54}$ she offered her readers a whole chapter devoted to Curries, and over twenty scattered recipes drawn from the Anglo-Indian cuisine of her day. She had a plausible source in her brother-in-law - Colonel James Dalgairns - who enjoyed a distinguished military career in Bengal, and retired early to be with his own extended family back in Scotland. According to contemporary accounts, Colonel Dalgairns embraced the local culture of Madras, immersed to the point of fathering two daughters by a local woman. ${ }^{55}$ These were the early days of British imperialism in India, a halcyon time for Indian food according to Colonel Kenney-Herbert, a muchpublished late nineteenth-century cookery writer known as "Wyvern" who was based in Madras. ${ }^{56}$ Wyvern viewed the 1820 s as a golden age for Indian food. When the memsahibs arrived later on in force, native cooks were taught how to deal with familiar British foods. But when the English merchants and officers were unencumbered by wives, strange new local dishes were created from scratch, curry powders were freshly ground, and unfamiliar ingredients were tried and tested. The range of spices and their proportions as directed by Mrs. Dalgairns are virtually the same as those set out by Indian writers themselves, and by Wyvern in his reminiscing mood. Among these are five recipes for Mulligatawny, a pepper-water soup; Kebobbed

54 R. Riddell, Indian Domestic Economy (Bombay: Gazette Press, 1849).

55 James Dalgairns was first posted to Bombay in 1808 , fully retiring in 1840 after service in Java, Bengal, and Madras. In his will he left money to both of his daughters living in India. There was a recorded incident that suggests that the Colonel was interested in Hindu culture. In 1836 he was formally denounced by a Catholic padre for ordering Roman Catholic drummers to participate in a native festival. See Kenneth Ballhatchet, "The East India Company and Roman Catholic Missionaries," Journal of Ecclesiastical History 44.2 (April 1993): 28I.

56 Wyvern (Col. A.R. Kenney-Herbert), Culinary Jottings for Madras, sth ed. (Madras: Higginbotham, I885). 
Currie (a "rich" dish concocted from small pieces of any meat, seasoned with curry powder plus additional spices, a whole head of garlic, onion, and chunks of apple); and Bradu Fagadu (lobster and shrimps mixed with spinach and an array of spices). The solidly AngloIndian dish Burdwan Stew is a perfect example of today's notion of "fusion" cookery: cold meat, soy, cayenne, lemon pickle and corach escavecke (a spicy sauce) are combined with ale or wine. ${ }^{57}$ Because the more exotic ingredients were not for sale where most of her British readers shopped, for coconut Mrs. Dalgairns substituted thick milk or cream; in place of dhal, dried split peas sufficed; mangoes were adequately replaced by apples and small fruits and tangy sauces were supplied by English bottlers.

Basil Hall sneaked in his recipe for Travelling Sandwiches on page 444 without advising the author, but it is hard to believe that he would not have shared recipes gleaned during a naval career that took him for long periods to the Far East, Africa, and North and South America. The Captain made notes on the exotic foods he encountered, gathering snippets of culinary lore, and later scattering them through a series of travel accounts. Having carefully watched native bearers in India and Java make curries, Hall decided "I could make a tolerable curry myself." He details the variety of ingredients that could be used and culinary styles to be followed, weighing the pros and cons of the different methods. In the account of his voyages around Java he observes for a whole paragraph the Malay method of boiling rice by steam. In South America he encountered a beef, vegetable, and Garbanza bean dish called Olla - "a dish celebrated in all lands where Spanish is spoken." 58

Like many English compilers of cookbooks, Mrs. Dalgairns provided her readers with a generous selection of dishes with French names, and other dishes that were French in origin but always popular with cooks in England. As Peter Brears has pointed out,

57 See K.T. Achaya in his Indian Food: A Historical Companion (Delhi: Oxford UP, 1998), 176 , where he cites Burdwan stew as a hybrid dish "conjured up between the English lady of the house and her Indian cook." Burdwan is a town 67 miles NW of Calcutta, in Sanskrit meaning "thriving, prosperous" (Hobson-Jobson: A Glossary of Colloquial Anglo-Indian Words and Phrases by Henry Yule [London: John Murray, I903], I30).

58 Captain Basil Hall, R.N., Fragments of Voyages and Travels (Edinburgh: Robert Cadell, I833), 2I-22; Voyage to Loo-Choo and Other Places in The Eastern Seas in the Year I8r6 (Edinburgh: Constable, 1826), I8; and Extracts from a Journal Written on the Coasts of Chili, Peru, and Mexico, in the Years I820, I821, 1822 (Edinburgh: Constable, I826), 120. 
it was probably through English cookbooks - such as The French Cook by Ude - that recipes for French foods were introduced to the Scottish gentry. ${ }^{59}$ In the early I80os French styles of cookery and French chefs reigned supreme among the British upper middle classes and nobility.

For the period after 1830, the Cadell Papers letter books that survive are concerned solely with Sir Walter Scott. Apart from Captain Hall's letters which acknowledge Cadell's reports of highly satisfactory sales, it is not possible to know if Cadell viewed the cookbook as a property that made money for him. We know from the letters that Cadell was "kind" to Mrs. Dalgairns, as the Captain had urged, but as a businessman first, he was direct but not effusive with his authors. And this author was a woman. By the late I820s Cadell had grown accustomed to the comfortable lifestyle that came with publishing Sir Walter Scott. In 1830 he confided in his diary a conviction that he would act on one principle, which was "to confine my attention almost exclusively to [the Waverley novels] and Sir Walter Scott's other publications, being convinced that steady prosperity is only to be attained by adhering to one good line." He goes on: "except the Waverley Novels, the only other work I have at press is a New Edition of Capt. Hall's Travels in North America - 500 copies - and the additions Sir Walter Scott is making to his Poetical Works." ${ }^{60}$ But Mrs. Dalgairns was always in the background, and just two months later Cadell instructed his London agents to prepare for two further editions - I50O copies each - of The Practice of Cookery. Simultaneously he was printing five to six thousand copies of each edition of Kitchiner's The Cooks Oracle, a cookbook that inspired imitation by Mrs. Beeton and other English writers, and provided a more than satisfactory income for its publisher. Sales of "Mrs. Dalgairns' Cookery" surged with advertisements placed prominently in the major newspapers, and with distribution to booksellers in London, Dublin, and other parts of the empire. However, it lacked some of the production values of its rivals. Cadell would not have even considered going to the expense of embellishing the text with engraved illustrations as he had for Sir Walter Scott

59 Peter Brear's introduction to Elizabeth Cleland's $A$ New and Easy Method af Cookery (1755) (Berwick-on-Tweed: Paxton Trust, and Totnes, Devon: Prospect Books, 2005) provides an excellent explanation of the "Scottishness" of Cleland's recipes before Scottish cookery was subjected to romantic interpretation (ixxii).

Diary entry, 20 Jan. I830, Diaries, MS 21020, Cadell Papers. 
and Captain Hall. In comparison with the other leading cookbooks, the lack of illustrations would have demoted it somewhat in the eyes of potential buyers. Editions of Mrs. Rundell featured an engraved frontispiece and nine plates. The lithographed frontispiece of Ude's French Cookery bore the author's portrait, followed by eight engraved plates in the text. And Kitchiner's The Cook's Oracle, in the London editions before Cadell purchased the copyright, were illustrated with engraved plates.

The true value of The Practice of Cookery, which was recognized by reviewers and by those who have cited it over the last I80 years, is that it is "more copious ... more various [and] more novel" than other comparable works. ${ }^{6 \mathrm{I}}$ There is no doubt that the cookbook would not have been published if Mrs. Dalgairns's friend Captain Hall had not talked it up with Cadell, and shepherded it through the many production stages leading to publication. But the Captain's participation aside, the book is able to stand on its own merits. Offering around 1500 recipes, it is indeed copious in comparison with Dr. Kitchiner (69I), Mr. Ude (86I), and Mrs. Rundell, whose unnumbered recipes are many fewer. Its variousness encompasses an international spectrum of foods and culinary styles. Its novelty is not that of chefs today who invent new dishes. Rather, in her Preface Mrs. Dalgairns advises the reader that "A perfectly original book of Cookery would neither meet with, nor deserve, much attention; because what is wanted ... is not receipts for new dishes, but clear instructions how to make those already established in public favour." She carried out this mandate faithfully, setting down careful directions for making hundreds of dishes that had not been published before, such as Montrose Cakes (flavoured with brandy, rosewater, currants, and spices), Come Again Tomorrow (small meat-filled pancakes), Prince of Wales's Catsup (elderberries with spices and anchovies), and Turkish sherbet (served as a refreshing drink). She takes Hannah Glasse's plain and simple Whim Wham - a kind of trifle - and with the addition of candied peels and fruits and red currant jelly turns it into gourmet fare. How fortuitous it was that in the late I820s Captain Hall was able to convince Robert Cadell to avert his eyes for a moment from the profitable writings of Sir Walter Scott and take on his old friend Catherine Emily Callbeck Dalgairns as a new author. For over thirty years and numerous editions, the recipes in "Mrs. Dalgairns' Cookery" enriched the repertoire of cooks in houses modest and grand, more than repaying her publisher's initial "risk."

6I The Spectator I3 June I829: 380 . 
“The Publication of Mrs. Dalgairns' Cookery: a fortuitous nineteenth century success story"

\section{SOMMAIRE}

En mars 1829, Robert Cadell d'Édimbourg publiait The Practice of Cookery de Mme Dalgairns. Ce livre de cuisine gagna très tôt des critiques plus que favorables dans des journaux écossais et anglais, les revues littéraires et la presse féminine. L'un des commentateurs souligna que l'ouvrage était plus volumineux, plus varié et novateur que ceux de Mme Rundell ou du Dr Kitchiner, deux noms adulés par les cuisinières anglaises du temps. Dès sa troisième édition le livre était déjà connu sous le titre de Mrs. Dalgairns' Cookery, conférant du même coup à son auteure l'honneur de figurer parmi les sommités de l'art culinaire. Même si un autre commentateur jugea cet ouvrage parmi les meilleurs jamais publiés, il le trouva par contre un peu trop écossais à son goût. Mais ce que l'on ignorait d'une manière générale, c'est que Mme Dalgairns était née, élevée et mariée dans l'Île-du-Prince-Édouard et issue d'une famille en vue de cette région. La genèse de ce livre de recettes puise dans les racines irlandaises, américaines et anglaises de l'auteure ainsi que dans son attrait pour un répertoire culinaire largement européen et exotique auquel des générations d'Écossais de haut rang étaient habitués.

Il est presque certain que l'auteure fut redevable de la publication fortuite de son livre de cuisine à une amité conquise à l'époque où elle vivait dans l'île-du-Prince-Édouard. Un chroniqueur de voyages de renom dont les textes furent diffusés par le même Cadell, le capitaine Basil Hall, devint en effet son agent et mentor. C'est lui qui en bout de ligne veilla à ce que l'ouvrage soit produit et publié. Grâce aux documents personnels de Robert Cadell qui doivent leur survie au fait que ce dernier fut l'éditeur de sir Walter Scott, on peut retracer les diverses étapes qui ont mené cette entreprise risquée à la réussite, que ce soit les soins apportés dans le choix du titre et la préparation de l'index, la présentation typographique, voire la publicité et la diffusion. Outre l'influence exercée par le capitaine Hall, le succès du Mrs Dalgairns' Cookery s'explique au fond par sa consécration jamais démentie et les recettes constantes qu'il généra jusqu'à sa $16^{\mathrm{e}}$ et dernière édition en 1861. Cet article tente de faire revivre un livre de cuisine injustement négligé de Mme Dalgairns dont la réputation fut éclipsée par l'idole de l'ère victorienne que fut Mme Beeton. 